\title{
Impact of Public External Debt on Exchange Rate in Nigeria
}

\author{
Zakaree S. Saheed (Corresponding Author) \\ Faculty of Arts and Social Sciences \\ Department of Economics, Nigerian Defence Academy \\ P.M.B 2109, Kaduna, Kaduna State, Nigeria \\ Tel: 234-80-3937-0901_E-mail: zakss_1@yahoo.co.uk \\ Ibrahim E. Sani \\ Department of Economics, University of Abuja \\ Abuja, Nigeria \\ Blessing O. Idakwoji \\ Department of Economics, Nigerian Defence Academy \\ Kaduna, Nigeria
}

Received: September 22, 2014 Accepted: October 17, $2014 \quad$ Published: March 30, 2014

doi:10.5296/ifb.v2i1. URL: http://dx.doi.org/10.5296/ifb.v2i1.1

\begin{abstract}
With continuous increase in public expenditures, and low capital formation in many developing countries, many governments have resorted into borrowing either or both within and outside the country. However, most borrowings come with interest attached, which results in debt servicing. Serving external debt may involve demand for foreign currency which tends to affect the exchange rate of the country. Hence, this study examines the impact of public external debt on exchange rate in Nigeria. Using the Ordinary Least Square, on the secondary data sourced from the $\mathrm{CBN}$ and DMO among other sources, findings reveals that all the dependent variables, that is, external debt, debt service payment and foreign reserve proved to be statistically significant in explaining exchange rate fluctuation in Nigeria within the period of observation, with debt service payment having the strongest effect (Coeff:
\end{abstract}




\section{Macrothink}

0.4443). Based on the finding, the study recommends that government should ensure that all public borrowing, where and when necessary, be directed towards productive economic activities which can generate returns to service and pay up the debt at maturity.

Keywords: Public debt, Foreign reserve, Exchange rate, Expenditure 


\section{Introduction}

Historically, in Nigeria, like so many other developing countries, public expenditure has recorded a continuous increase over time, especially, as the government assumes an active role in the development of the economy by trying to put in place the infrastructure and institutional superstructure necessary for economic growth and development. The tendency of increasing public expenditure can be attributed to factors like the growing population and increasing urbanization, which require increase in the sheer of scale of state services and traditional functions, including defence particularly where the country faces one form of crisis or the other. For instance, the insurgences from the Niger Delta militants, and the current Boko Haram crisis in some states in the north-eastern part of Nigeria has forced the government to increase its spending on defence. Meanwhile, better quality services imply a higher cost (Bhatia, 2010).

Most less developed countries are characterised by a shortage of capital resources to meet the increasing public expenditures. Since primary products consitute a large fraction of the exports of most developing countries, the drastic decline in the prices of primary products in the 1980 means reduction in the foreign reserve use for financing external payments, and it is generally expected that developing countries, facing a scarcity of capital, will acquire external debt to supplement domestic saving (Aliko \& Arowolo, 2010). Hence, resorting to public borrowing.

The issue of Nigeria's public debt became important in recent times especially prior to the period of debt forgiveness because of its magnitude and the amount which was required to service such debts, as well as, its attendant possible effects on different operating sectors of the economy especially the banking sector and the growth of the economy at large.

In 1981, the Nigerian total outstanding external debt was N2,331.2 million, and by the end of 1982, it had skyrocketed to N8,819.4million. Progressively increased to N17,290.6 million and N42,229.5million in 1985 and 1986 respectively. By the end of October 1987, it had hit the mark of N100,787.6 million (USD 23,445.3 million). Although under the Nigerian constitution, only the Federal Government could borrow from abroad, many state governments however, have successfully negotiated foreign loans and subsequently obtained Federal Government Guarantees. At the end of September 1988, according to the CBN, the total outstanding external debt stood at N133.956million and attained N212,750.7 million in 1989 , and rose to $\mathrm{N} 3,097,384$ million in 2000. This figure however, dropped by about 13 percent to stand at N2,695,072 million in 2005, when the Nigerian government reached an agreement with its Paris Club creditor for a debt relief which led to an overall reduction of Nigerian debt stock by US30 billion (N3,966 billion). The deal was completed in 2006 when the government of Nigeria made its final payment and was cleared of its debt with the Paris Club. Hence, as at the end of 2006, Nigerian total external debt burden has reduced to just N451,561.7 million. However, by 2010, the external debt has again risen by about 52.8 percent to attain N689,845.3 million, which further rose by about 99.1 percent to stand at $\mathrm{N} 1,373,569.83$ million in 2013. 


\section{Macrothink}

Though the debt, if properly utilized, is expected to help the debtor country's economy, however, the management of debt by way of service payment, that is, the sum of principal payments and interest actually paid in foreign currency, especially in foreign currency tends to affect exchange rate. At a point in 2000, according to IMF and the World Bank data, Nigeria debt service payment was estimated at approximately US\$ 1,854.82 million (N189,376.71million), which is about 107.9 percent of the country's external reserve. In 2005, it attained US\$8,870.8 million (about N1,172,719.23 million) or about in 130.7 percent of Nigeria external reserve. However, following the debt relief package received by the country, the country's debt service payment followed a decreasing trend as it fell to only US\$6,643.9 million (N878,325.76 million), which is about 110.8 percent of the external reserve in 2006, and further decreased to US\$369.22 million (N55,493.83million) or 86.5 percent less of the external reserve in 2010, while in 2013 the total debt service payment was just US\$297.33 million (N46,760.93million). Meanwhile, the demand for foreign currency tends to have a considerable effect on the rate of exchange in the country.

Within the period of observation, according to the Central Bank of Nigeria (2012), exchange rate in Nigeria fluctuates by various degree of appreciation and depreciation of Naira against USD. For example, between 1981-1984, the naira depreciated by 23.5 percent against the United State of American dollar. Between 1984-1985, the naira further depreciated by 16.9 percent, while it experienced a sharp depreciation of 2,367.1 percent between 1985-1993. Between 1993-1998, and 1998-2010, the Naira depreciated against US dollar by 320.35 percent and 62.1 percent respectively. The Nigerian Naira experienced highest depreciation against US Dollar between the period of 1985-1993, when it dropped by 2,367.1 percent.

Given the foregoing, the challenge of this paper is to critically investigate:
i. Effect of external debt on exchange rate in Nigeria
ii. Effect of debt service payment on exchange rate in Nigeria
iii. Effect of foreign reserve on exchange rate in Nigeria

To this end, the paper is organized into five sections. Following this introduction is section 2, which focuses on literature review and theoretical framework. Section 3 discusses the methodology, while section 4 summaries the finding and proffers policy recommendation.

\section{Literature Review and Theoretical Framework}

This section discusses relevant literature and theoretical framework on the linkage between public debt and exchange rate.

\subsection{Literature Review}

National Debt, also known as public debt, is the sum total of government financial obligations, resulting from state's borrowing from its population, foreign governments, or international institutions such as the International Bank for Reconstruction and Development. Public debts tend to be large-scale credit operations and are contracted on a national scale by central governments and on a lesser scale by provincial, regional, district, and municipal 
administrative bodies.

United States Department of the Treasury in 2010, defined public debt as the debt owed by the central government and other federal states of any country. Meanwhile the World Bank (1998), sees public debt as the resource of money generated outside or within the country that is given to the government of any given country with interest attached to the payment when due. To the lender, the interest is the most important part of debt, while the same interest is the most frustrating part of debt to the borrower.

According to Bamidele and Joseph (2013), debt is defined as the resource or liquid asset that is used up in an organization, without being contributed by the owner and does not in any other way belong to the organisation. However, a public debt could be external or internal.

External debt is the amount, at any given time, of disbursed and outstanding contractual liabilities of residents of a country to nonresidents to repay principal, with or without interest, or to pay interest, with or without principal (The World Bank et al., 1998). The liabilities which fall within the core definition include: currency and transferable deposits, other deposits, short-term bills and bonds, long-term loans (not classified elsewhere), and trade credit and advances. Such foreign borrowings are meant to supplement national resources (domestic) without an immediate reduction in other uses of resources, whether for consumption or capital formation (Musgrave, 1959).

From the point of view of the creditors, external debts can be classified into two broad categories, that is, official creditors and private creditors. Official creditors include international organizations, such as, the World Bank Group, while the private creditor includes the Euro-Dollar market and other international capital markets. Loans from these two sources usually come on "soft" and concessionary terms and have relatively longer maturity term and low rates of interest (Anyanwu, 1988).

Internal debt involves a re-arrangement of assets such that citizens surrender current purchasing power in return for government securities, and no increase in real resource is directly created as a result. That is, it is a situation whereby the borrowing unit acquires the money from itself (lends to itself) hence taxpayers can be said to be borrowing from themselves. Such internal debt include loans through the issues of treasury bills, treasury certificates, development stocks, ways and means advances, etc. Thus government creates internal debt by tapping personal and corporate savings directly and indirectly. The issue of government bonds or securities constitutes direct government absorption of domestic savings. An indirect method of absorption of private sector savings by government is by borrowing from the banking system through the sale of bonds and securities.

Eaton (1993) cited in Lawrence and Michael (2012), made simple distinction between the various stock and flows associated with debt. Regarding to stocks, a major distinction is made between disbursed and undisbursed debt. Whereas undisbursed debt is composed of mere commitment made by lenders and are, therefore, not accumulating interest, disbursed debt consists of commitment made by the lender that have been drawn on and have accumulated unpaid interest. Putting differently, unpaid interest obligations are part of disbursed debt. 
Meanwhile, debt can be classified into reproductive debt and dead weight debt. When a loan is obtained to enable the state or nation purchase some sort of assets, the debt is said to be productive e.g. money borrowed for acquiring factories, electricity, and refineries etc. However, debt undertaking to finance war and expenses on current expenditure are dead weight debt. Where such obligation is owed to a foreign government or institutions, and servicing the interest required payment in foreign currency, it tends to affect the exchange rate.

\subsection{Theoritical Frame Work}

\subsubsection{Threshold School of Thought (Debt-Later Curve Thesis)}

The burden of external debt is the concern of threshold school of thought which emphasizes the non-linear relationship between debt and growth (Calvo, 1998). It links debt and growth to problem of capital flight where at high debt levels growth falls. According to the threshold theory, the fall in growth is due to the higher distortionary tax burden on capital required to service the debt. It leads to lower rate of return on capital, lower investment and hence lower growth. It maintains that low debt regimes have higher growth rate and lower strand of thought in the debt-growth nexus sees external debt as capital inflow with positive effect on domestic savings and investment and thus on growth which leads to poverty reduction via appropriate targeting of domestic savings and investment (Calvo, 1998)

Some economists do not view external debt as indispensable for the economic development of LDCs. To them, public debt both external and internal but especially external, does not help in overcoming balance of payment difficulties and also does not avoid inflationary pressures. In their opinion, public debt encourages governments of LDCs to embark on ambitious and ambiguous plans involving large expenditures financed by inflationary monetary and fiscal policies and also run down their external reserve.

\subsubsection{Ricardo Theory of Public Debt}

Ricardo's theory of public debt was based on an emphasis of the fact that the primary burden to the community was derived from wasteful nature of public expenditure itself rather than from the methods adopted to finance such expenditure. Regarding the question of financing public expenditure, his view was that the requisite funds would ultimately have to be drawn from the liquid resources of the community and that in point of economy, it would make no great difference whether such funds were raised by taxes or by loans. However, where the funds were raised through the later, it would be referred as public debt. External debt involves debt servicing, which in most cases require payment in foreign currency. Whereas, the continue increase or decrease in demand for foreign currency tends to influences the exchange rate.

\subsection{Emperical Literature}

Many researchers both within and outside Nigeria, have focused their research on public debt and exchange rate. For instance, Alam and Taib (2003), adopted a model wherein the relationship of external public debt with budget deficit, current account deficit and exchange rate depreciation were empirically tested for Debt Trap Countries (DTC) and Non Debt Trap 
Countries (NDTC) of Asian pacific development countries. The result obtained indicates a positive relationship of external public debt with budget deficit, current account deficit and exchange rate depreciation. However, the strength of relationship varies in DTC and NDTC. Meanwhile the study only focused on the relationship between the variables of external debt and exchange rate rather than their impacts. More so, it focused on Asian economies which, differ to some extent, from that of the research area (Nigeria), hence may not be relevant to Nigerian situation.

Sene (2004), examines the relationship between external public debt and equilibrium real exchange rate in developing countries using an extension of Obstfield and Rogoff model. The findings show that debt overhang tends to appreciate real exchange rate in the long run. Another author, Lin (1994), examines the steady-state effect of government debt on the real exchange rate within a two-country overlapping generations (OLG) model with production, and came up with findings which indicates that increase in government debt depreciates the real exchange rate of the country.

Patrawimolporn (2007), evaluates the effect of exchange rate on debt, debt services and public debt management in Thailand, using a simple differentiation technique. His findings reveal that exchange rate volatility affects debt services since a significant amount of debt services was saved when the exchange rate was adjusted. However, the study failed to show the effect of either the public debt or debt services on exchange rate itself. More so, since the study focus on Thailand economy, the findings may not be absolutely applicable to Nigeria.

In Nigeria, Ogege and Ekpudu (2010), employs the OLS to test the relationship between debt burden and the growth of the Nigerian economy, and came up with the results that indicates that there is a negative relationship between debt stock and gross domestic products. Here, the focus of the study is on gross domestic product, rather than exchange rate which is the interest of the current study.

Ijeoma (2013), on her part, made use of linear regression model to empirically assess the impact of debt variables, which include external debt stock, external debt service payment on selected macroeconomic variables including gross domestic product and gross capital formation. The results reveal that there is a significant relationship between Nigerian debt service payment and gross fixed capital formation. The result further shows that exchange rate fluctuations affects external debt shock, external debt service payment and the nation's economic growth. Even though, the study considered Nigerian economy, however the result only shows the effect of exchange rate on external debt, whereas, the emphasis of the current study is on the impact of public debt on exchange rate, hence this study tends to bridge the gaps observed in previous studies examined.

\section{Methodology}

\subsection{Sources of Data}

This paper relied on secondary data (time series data), to empirically investigate the effect of public debt on exchange rate, based on data covering the period 1981 to 2013. External reserve is measured by total sum of foreign exchange reserve. The values of External debt, 


\section{Macrothink}

Debt service payment and Foreign reserve were converted to the Nigerian currency (Naira) based on the exchange rate of the corresponding year. Data on these variables were sourced from Central Bank of Nigeria (2012), Debt Management Office (2014), International Monetary Fund and World Bank International Financial statistics and Data file, as well as the World Bank Global Economic Monitor (2014).

\subsection{Model Specification}

In order to achieve the objectives of the study, the linear regression model is adopted to estimate the impact of public debt on exchange rate in Nigeria. The model is specified thus;

$$
E R=f(E D T, D S P, F R)
$$

Where

$\mathrm{ER}=$ Exchange Rate;

$\mathrm{EDT}=$ External Debt;

DSP $=$ Debt Service Payment;

$\mathrm{FR}=$ Foreign Reserve.

In stochastic form equation (1) becomes:

$$
E R=\beta_{0}+\beta_{1} E D T+\beta_{2} D S P+\beta_{3} F R+U
$$

Prior to estimation of the model, standard econometric tests, that is, stationarity tests were conducted to tests for its stochastic properties through unit root tests in order to avoid estimating spurious regression results, while co-integration test was used to analyze the relationship between public debt and exchange rate.

\section{Data Analysis and Interpretation}

\subsection{Data Analysis}

Table 1. Results of stationarity (unit root) test

\begin{tabular}{|c|c|c|c|c|c|}
\hline Variable & $\begin{array}{c}\text { Critical } \\
\text { Value }\end{array}$ & $\begin{array}{c}\text { ADF-Statistic } \\
\text { at Level }\end{array}$ & Critical Value & $\begin{array}{c}\text { ADF-Statistic at } 1^{\text {st }} \\
\text { Difference }\end{array}$ & Order of Integration \\
\hline LOGER & -1.93238 & -3.653730 & -4.794693 & -2.960411 & $\begin{array}{c}\text { Stationary at first } \\
\text { difference }\end{array}$ \\
\hline LOGDBT & -2.291299 & -2.960411 & -4.213549 & -3.661661 & $\begin{array}{c}\text { Stationary at first } \\
\text { difference }\end{array}$ \\
\hline LOGDSP & -2.108742 & -2.957110 & -4.21500 & -2.960411 & $\begin{array}{c}\text { Stationary at first } \\
\text { difference }\end{array}$ \\
\hline LOGFR & -0.144064 & -2.957110 & -5.27843 & -2.963977 & $\begin{array}{c}\text { Stationary at first } \\
\text { difference }\end{array}$ \\
\hline
\end{tabular}

Source: researchers' computations, E-views, 7.0, 2014. 


\section{Mll Macrothink}

Table 1 above; present the summary of unit root tests results at both level and first difference. The ADF tests were conducted on all the variables, and the results of the unit root tests showed that all the variables are stationary at first difference and as well as constant at $5 \%$ level of significance. As the variables are found to be stationary, it implies that they are cointegrated. In other words, the result implies that the joint probability distribution of these variables do not change when shifted in time, as such, the mean and variance, if present, are also expected not to change over time.

Table 2. Regression result

\begin{tabular}{|c|c|c|c|c|}
\hline \multicolumn{3}{|c|}{ Dependent Variable: LOGER } & & \\
\hline \multicolumn{3}{|c|}{ Method: Least Squares } & & \\
\hline \multicolumn{3}{|c|}{ Date: $03 / 14 / 15 \quad$ Time: 06:47 } & & \\
\hline \multicolumn{5}{|l|}{ Sample: 19812013} \\
\hline \multicolumn{5}{|c|}{ Included observations: 33} \\
\hline Variable & Coefficient & Std. Error & t-Statistic & Prob. \\
\hline LOGEDT & 0.352062 & 0.085624 & 4.111742 & 0.0003 \\
\hline LOGDSP & 0.444348 & 0.093968 & 4.728737 & 0.0001 \\
\hline LOGFR & 0.403125 & 0.050278 & 8.017992 & 0.0000 \\
\hline $\mathrm{C}$ & -10.78454 & 0.598715 & -18.01281 & 0.0000 \\
\hline R-squared & 0.954784 & \multicolumn{2}{|c|}{ Mean dependent var } & 3.112121 \\
\hline Adjusted R-squared & 0.950106 & \multicolumn{2}{|c|}{ S.D. dependent var } & 1.934830 \\
\hline S.E. of regression & 0.432182 & \multicolumn{2}{|c|}{ Akaike info criterion } & 1.273275 \\
\hline Sum squared resid & 5.416668 & \multicolumn{2}{|c|}{ Schwarz criterion } & 1.454670 \\
\hline Log likelihood & -17.00903 & \multicolumn{2}{|c|}{ Hannan-Quinn criter. } & 1.334309 \\
\hline F-statistic & 204.1198 & \multicolumn{2}{|c|}{ Durbin-Watson stat } & 1.056301 \\
\hline Prob(F-statistic) & 0.000000 & & & \\
\hline
\end{tabular}

Source: Computed from Eview 7.0.

$$
\begin{aligned}
\text { LOGER }= & \beta_{0}+\beta_{1} \text { LOGEDT }+\beta_{2} \text { LOGDSP }+\beta_{3} \text { LOGFR }+\varepsilon \\
= & 10.7845+0.35206 \mathrm{EDT}+0.4443 \mathrm{DSP}+0.4031 \mathrm{FR} \\
& (18.0128)
\end{aligned}
$$

\subsection{Discussion}

The results in table 4.2 above show a robust Adjusted R-square of about 0.9501, indicating that about 95.01 percent change in dependent variable (ER) is jointly explained by the explanatory variables (EDT, DSP, and FR), while, only 4.99 percent change in the dependent variable, that is, exchange rate fluctuation, can be said to be explained by factors outside the model. The The F-stat of 204.119 indicates that the entire model is significant. 
The result indicates that all the explanatory variables are statistically significant in explaining exchange rate in Nigeria with the t-statistic value of $4.1117,4.7287$ and 8.01799 for EDT, DSP, and FR respectively. Also all the explanatory variables have positive impact on exchange rate fluctuation. By implication, a change in any of the explanatory variables will causes fluctuation in the exchange rate in Nigeria. For instance, a percentage change in the External Debt, Debt Service payment and Foreign Reserves will fluctuate the exchange rate by 0.35 percent, 0.44 percent, and 0.40 percent respectively.

The foreign reserve's positive impact on exchange rate can be attributed to the observation made by Calvo and Reinhart (2002), that most developing countries seem to be more tolerant of foreign reserve fluctuations than the exchange rate fluctuation. Hence, a country experiencing exchange rate fluctuations use the foreign reserve stock to interven in foreign exchange market to dampen the exchange rate volatility. This result confirms the general belief that volatility in exchange rate is greatly influenced by the foreign reserve.

\section{Conclusion and Recommendation}

Based on the analysis carried out on the secondary data sourced from the Central Bank of Nigeria, it is observed, in the context of this study, all the explanatory variables examined, have a statistically significant effect on exchange rate within the period of observation. However, debt service payment has the strongest effect on exchange rate fluctuation in Nigeria. Based on the findings, it is therefore recommended that external debt, where and when necessary, should be directed towards only productive economic activities, which can generate enough returns to upset the debt servicing and principal.

\section{References}

Ajayi, S. I. ( 2002). Macroeconomic Approach to External Debt: The case of Nigeria. AERC Research paper no.8. Nairobi: AERC.

Alam, N., \& Taib, F. (2013). An Investigation of the Relationship of External Public Debt with Budget Deficit, Current Account Deficit and Exchange Rate Depreciation in Debt Trap and Non-Debt Trap Countries. European Scientific Journal, 9(22).

Aluko, F., \& Arowolo, D. (2010). Foreign Aid, the Third World's Debt Crisis and the Implication for Economic Development: The Nigeria Experience. African Journal of Political Science and International Relations, 4(4), 120-127.

Amakom, U. S. (2003). Nigeria Public Debt and Economic Growth: An Empirical Assessment of Effects on Poverty. Nigeria: African Institute for Applied Economics, EconWPA.

Asogwa, R. C. (2005). Domestic Government Debt Structure, Risk Characteristics and Monetary Policy Conduct, Evidence from Nigeria. Retrieved from http://www.imf.org/external/np/res/seminars/2005/ macro/pdf/asogwa.pdf

Bamidele, T. B., \& Joseph, A. I. (2013). Financial Crisis and External Debt Management in Nigeria. International Journal of Business and Behavioural Sciences, 3(4). 
Calvo, G. A., \& Reinhart, C. M. (2002). Fear of floating. Quarterly Journal of Economics, 117(2), 379-408. http://dx.doi.org/10.1162/003355302753650274

CBN. (2012). Annual Statistical Bulletin, 24.

Claessens, S., Detragiache, E., Kanbru, R., \& Wickham. (1997). Analytical Aspects of the Debt Problems of Heavily Indebted Poor Countries. In Zubairlqbal \& Ravi (Eds.), External Finance for low-Income Countries.

Dickey, D. A., \& Fuller, W. A. (1979). Distribution of the Estimators for Autoregressive Time Series with a Unit Root. Journal of the American Statistical Association, 74, 427-431.

Eseonu, M. (2006). Sub-Sahara African Debt Crisis: Analysis and Forcast Based on Nigeria. Emerald Group Publishing Limited.

Greene, J. (1989). The External Debt Problem of Sub-Saharan Africa. IMF Staff Papers, 36(4), 836-874. http://dx.doi.org/10.2307/3867242

Ijeoma, N. B. (2013). An Empirical Analysis of the Impact of Debt on the Nigerian Economy. International Journal of Arts and Humanities, 2(7), 165-191.

Ogege, S., \& Ekpudu, J. E. (2010). The Effect of Debt Burden on the Nigerian Economy. Journal of Research in National Development, 8(2).

Omotoye, O. R., Sharma, H. P., Ngassam, C., \& Eseonu, M. (2006). Sub-Saharan Africa's Debt Crisis: Analysis and Forecast Based on Nigeria. Managerial Finance, 32(7), 606-620. http://dx.doi.org/10.1108/03074350610671593

Patrawimolporn, P. (2007). Effect of Exchange Rate on Debt, Debt Services and Public Debt Management in Thailand in the 1980s. Asian Economic Journal, 5(3).

Samson, O., \& Jonathan, E. E. (2010). The Effect of Debt Burden on Nigerian Economy. Journal of Research in National Development, 8(2).

Sanusi, J. O. (2011). The Impact of the Global Financial Crisis on the Nigerian Capital Market and the Reforms. Lecture delivered at the 7th Annual Pearl Awards and Public Lecture Held at the Muson Centre, Onikan, Lagos.

Sene, B. (2004). The Impact of Debt Overhang on Equilibrium Real Exchange Rate in Developing Countries: A Theoretical Model. EURISCO Working Paper, No. 04-17. http://dx.doi.org/10.2139/ssrn.640481

Soludo, C. C. (2003). Debt, Poverty and Inequality. In O. I. Soludo \& Muhtar (Eds.), The Debt Trap In Nigeria (pp. 23-74). Africa World Press NJ.

Stiglitz, J. E. (2000). Economic of the Public Sector (3rd ed., p. 790). New York and London: W.W. Norton \& Company.

Tajudeen, E. T. (2012). Public Debt and Economic Growth in Nigeria. Evidence from Granger Causality. American Journal of Economics. 


\section{Appendix. Data Presentation (N'Million)}

\begin{tabular}{|l|l|l|l|l|}
\hline YEAR & Public External Debt & DSP & FR & ER \\
\hline 1981 & 2331.2 & 1092.30 & 56194.8 & 0.61 \\
\hline 1982 & 8819.4 & 1400.53 & 12324.3 & 0.67 \\
\hline 1983 & 10577.7 & 1847.07 & 7171.4 & 0.72 \\
\hline 1984 & 17300.6 & 3091.3 & 5479.7 & 0.76 \\
\hline 1985 & 41452.4 & 3941.52 & 6601.8 & 0.89 \\
\hline 1986 & 100789.1 & 4142.53 & 18922.05 & 2.02 \\
\hline 1987 & 133956.3 & 4447.76 & 62554.27 & 4.02 \\
\hline 1988 & 240393.7 & 10035.37 & 72266.81 & 4.54 \\
\hline 1989 & 298614.4 & 15648.25 & 43953.22 & 7.39 \\
\hline 1990 & 328453.8 & 26817.77 & 40293.2 & 8.04 \\
\hline 1991 & 544264.1 & 29182.50 & 48620.04 & 9.91 \\
\hline 1992 & 633144.4 & 41772.10 & 33391.95 & 17.3 \\
\hline 1993 & 648813 & 32876.51 & 173810.7 & 22.05 \\
\hline 1994 & 716865.6 & 40970.88 & 95629.02 & 21.89 \\
\hline 1995 & 617320 & 40122.27 & 32345.01 & 21.89 \\
\hline 1996 & 617320 & 48784.71 & 25895.59 & 21.89 \\
\hline 1997 & 595931.9 & 30993.96 & 73492.11 & 21.89 \\
\hline 1998 & 633017 & 29157.24 & 93776.73 & 21.89 \\
\hline 1999 & 2577474 & 99368.78 & 58814.6 & 92.69 \\
\hline 2000 & 3097384 & 189376.71 & 91089.2 & 102.1 \\
\hline 2001 & 3176291 & 287127.46 & 123329.8 & 111.9 \\
\hline 2002 & 3932885 & 180734.50 & 103104.1 & 120.9 \\
\hline 2003 & 4478329 & 213084.40 & 91701.66 & 129.4 \\
\hline 2004 & 4890269 & 231119.74 & 144753.1 & 133.5 \\
\hline 2005 & 2695072 & 1172719.23 & 508279.3 & 132.2 \\
\hline 2006 & 451561.7 & 878325.76 & 416643.1 & 128.7 \\
\hline 2007 & 431079.9 & 157807.21 & 544704.7 & 125.9 \\
\hline 2008 & 493180.2 & 68550.44 & 701674.6 & 118.6 \\
\hline 2009 & 590441.1 & 74650.27 & 536428.3 & 148.9 \\
\hline 2010 & 689845.3 & 55493.83 & 411978.5 & 150.3 \\
\hline 2011 & 876846.59 & 65599.74 & 5611438.7 & 154.74 \\
\hline 2012 & $1,016,721,69$ & 45945.80 & 6875961.69 & 156.81 \\
\hline 2013 & $1,373,569.83$ & 46760.93 & 7297799.81 & 157.27 \\
\hline & & & & \\
\hline
\end{tabular}

Source: culled from CBN, DMO, IMF, World Bank.

\section{Copyright Disclaimer}

Copyright for this article is retained by the author(s), with first publication rights granted to the journal. This is an open-access article distributed under the terms and conditions of the Creative Commons Attribution license (http://creativecommons.org/licenses/by/3.0/). 